\title{
Development and characterization of microsatellite loci in Grevillea robusta
}

\author{
Camila Mantello ${ }^{1}$, Daiane Rigoni Kestring ${ }^{2 *}$, Valderês Aparecida Sousa ${ }^{2}$, Ananda Virginia Aguiar $^{2}$, \\ Anete Pereira Souza ${ }^{1}$ \\ From IUFRO Tree Biotechnology Conference 2011: From Genomes to Integration and Delivery \\ Arraial d'Ajuda, Bahia, Brazil. 26 June - 2 July 2011
}

\section{Background}

Grevillea robusta is a native tree to the subtropical coastal regions of northern New South Wales and southern Queensland in Australia. In Brazil, Embrapa Forestry and its partners have established many provenance/progeny tests to increase the species genetic basis and aim to implement a breeding program to improve timber production. Genetic variability of these tests has been monitored through the assessment of quantitative traits. However, the genetic evaluation of materials based on phenotypic traits is influenced by many environmental factors. Estimates of some genetic parameters such as gene flow and parentage are possible using molecular tools as most common molecular marker, microsatellite (Simple Sequence Repeats, SSRs) which are codominant and highly polymorphic. Genetic markers have intensively applied for the main strategies in breeding programs, especially when economically important traits are difficult measure because of low heritability. The aim of this study was develop microsatellite markers for Grevillea robusta through enriched library in order to estimate the genetic diversity and structure of the species, and direct efforts for the conservation and management of its active germplasm banks.

\section{Methods}

The genomic-enriched library was constructed following the protocol described by [1]. The genomic DNA was digested with AFA $I$ and enriched in $(\mathrm{CT})_{8}$ and $(\mathrm{GT})_{8}$ repeats. Enriched fragments were amplified by polymerase chain reaction (PCR), connected to a pGEM T-easy

* Correspondence: drigoni@cnpf.embrapa.br

${ }^{2}$ Embrapa Florestas, Brazil

Full list of author information is available at the end of the article vector and transformed into competent XL1- blue Escherichia coli cells. The positive clones were selected using the B-galactosidase gene and then grown overnight in an HM/F medium with ampicillin. After PCR, 95 positive clones were sequenced in both directions using the T7 and SP6 primers as well as the Big Dye terminator Kit. The sequences were assembled and edited in Seqman (DNAStar) and the repetitive regions were found using the Simple Sequence Repeat Identification Tool [2]. Primer Select (DNAStar) and Primer 3 plus were softwares used to design primer pairs flanking the microsatellite regions.

\section{Results and conclusions}

Of the ninety five sequences cloned, seven contained microsatellite sequences. Only five of them showed repeats and adequate flanking regions for primer design. The observed proportion of trinucleotide was $4.21 \%$ (4), while tetranucleotide and pentanucleotide were $2.11 \%$ (2) and $1.05 \%$ (1), respectively. Of the total of nucleotides found $100 \%$ are simply perfect. The explanation for this low yield sequences $(7,4 \%)$ can be attributed to the genomic-enriched procedure. These sequences will be validated and promptly used to estimate the genetic diversity, gene flow and parentage of the Brazilian germoplasm collections.

\section{Author details \\ 'UNICAMP, Brazil. ${ }^{2}$ Embrapa Florestas, Brazil.}

Published: 13 September 2011

\section{References}

1. Billote N, Risterucci AM, Baurens FC: Microsatellite enriched libraries: applied methodology for the development of SSR markers in tropical crops. Fruits 1999, 54:277-288.
C Biomed Central

() 2011 Mantello et al; licensee BioMed Central Ltd. This is an open access article distributed under the terms of the Creative Commons Attribution License (http://creativecommons.org/licenses/by/2.0), which permits unrestricted use, distribution, and reproduction in any medium, provided the original work is properly cited. 
2. Temnykh S, DeClerck G, Lukashova A, Lipovich L, Cartinhour S, McCouch S: Computational and experimental analysis of microsatellites in rice (Oryza sativa L.): frequency, length variation, transposon associations, and genetic marker potential. Genome Research 11:1441-1452.

doi:10.1186/1753-6561-5-S7-P16

Cite this article as: Mantello et al:: Development and characterization of microsatellite loci in Grevillea robusta. BMC Proceedings 2011 5(Suppl 7): P16

Submit your next manuscript to BioMed Central and take full advantage of:

- Convenient online submission

- Thorough peer review

- No space constraints or color figure charges

- Immediate publication on acceptance

- Inclusion in PubMed, CAS, Scopus and Google Scholar

- Research which is freely available for redistribution

Submit your manuscript at www.biomedcentral.com/submit 